\title{
Antimicrobial activity of essential oil and growth of Ocimum basilicum (L.) inoculated with mycorrhiza and humic substances applied to soil
}

\author{
F. Morelli ${ }^{1}$, L. Ferarrese ${ }^{2}$, C.L. Munhoz ${ }^{2}$ and O. Alberton ${ }^{2}$ \\ ${ }^{1}$ Curso de Biomedicina, Universidade Paranaense, Umuarama, PR, Brasil \\ ${ }^{2}$ Programa de Pós-Graduação em Biotecnologia Aplicada à Agricultura, \\ Universidade Paranaense, Umuarama, PR, Brasil \\ Corresponding author: O. Alberton \\ E-mail: odair@prof.unipar.br / oalberton@yahoo.com.br
}

Genet. Mol. Res. 16 (3): gmr16039710

Received April 24, 2017

Accepted July 3, 2017

Published July 28, 2017

DOI http://dx.doi.org/10.4238/gmr16039710

Copyright $(2017$ The Authors. This is an open-access article distributed under the terms of the Creative Commons Attribution ShareAlike (CC BY-SA) 4.0 License.

\begin{abstract}
Mycorrhizal association increases the absorption of water and nutrients by plants, and thus, affects their metabolism. This study aimed at assessing the single and conjoint effects of the arbuscular mycorrhizal fungus (AMF) Claroideoglomus etunicatum and soil's humic substances (HS) on the composition of essential oil (EO), its antimicrobial activity, and development of basil (Ocimum basilicum L.). The experimental design was completely randomized in a $2 \mathrm{x}$ 2-factorial design (with and without AMF and HS) with 10 replications as follows: T1 - without AMF inoculation and without HS addition; T2 - with AMF inoculation and with HS (2 L/ha); T3 - without AMF inoculation and with HS; T4 - with AMF inoculation and with HS. Plants were grown in pots with $5 \mathrm{~kg}$ sterile soil in a greenhouse for 6 months. Then, they were harvested and evaluated for spore density, AMF root colonization, shoot dry matter (SDM), yield and chemical composition
\end{abstract}

Genetics and Molecular Research 16 (3): gmr16039710 
of EO as well as minimum inhibitory concentration, used to compare the antimicrobial effect of EO in nine bacteria. The addition of HS to the soil increased the spore density of AMF and SDM $(\mathrm{P}<0.001)$. The AMF inoculation with and without HS increased the EO yield of basil $(\mathrm{P}<0.001)$. The treatments altered the composition of the basil EO, in which a total of fourteen compounds were detected. In treatments with AMF and/or HS, linalool (28.64 to $42.94 \%)$ and estragole (27.53 to $47.17 \%$ ) were the major compounds. However, in the control (without AMF and HS), eugenol (33.90\%) was the major compound. The EO showed low microbial activity against bacteria Bacillus cereus, Salmonella enterica serovar typhi, Shigella flexneri, Klebsiella pneumoniae, and Xanthomonas axonopodis pathovar begoniae. AMF inoculation and HS addition could improve the development of basil, increase EO yield, alter the EO chemical composition and its major compounds, but presented low or none microbial activity against most of the bacteria tested in this study.

Key words: Herbal medicines; Natural antibiotics; Linalool; Estragole; Mycorrhizal fungi

\section{INTRODUCTION}

Medicinal, spicy, and aromatic plants have been used since antiquity by our ancestors around the world. In general, these plants produce components derived from secondary metabolism. Stable oil composition and high amount of its active components are a market prerequisite for medicinal, spice, and aromatic plants. However, such requirements depend on the farming system and environment (Urcoviche et al., 2015; Hanif et al., 2017; Mohr et al., 2017; Lermen et al., 2017).

Less aggressive cultivation methods are highly recommended for the production of medicinal, herbal, and aromatic plants. Either growth or vigor of plants should be promoted while maintaining product quality. Plants should be well nourished and resistant to biotic and abiotic stresses. These crops should produce large amounts of biomass and medicinal substances inherent to the species without the need for supplements and/or agrochemicals (Urcoviche et al., 2015; Lermen et al., 2017). The use of soil microorganisms, as arbuscular mycorrhizal fungi (AMF), is an alternative to increase the productivity of this type of plants since AMF contribute to a better development of them (Zubek et al., 2012; Befrozfar et al., 2013; Lermen et al., 2015a, Verma et al., 2016).

AMF are soil microorganisms that belong to Phylum Glomeromycota, Class Glomeromycetes and form a monophyletic group of fungi classified into four orders, 13 families, and 19 genera, with somewhat 215 species already described (Urcoviche et al., 2014). There are few studies on mycorrhization with medicinal, spicy, and aromatic plants. Some of them have already demonstrated that mycorrhizae promote in plants an increase in the absorption of nutrients such as phosphorus and nitrogen, an improvement in growth and an increase in the production of secondary metabolites with medicinal and antimicrobial activities (Zubek et al., 2012; Lermen et al., 2015b; Urcoviche et al., 2015; Verma et al., 2016). Few studies are found in the literature on the effects of AMF inoculation on the growth and production

Genetics and Molecular Research 16 (3): gmr16039710 
of essential oil (EO) of basil. In a recent study, Tiwari et al. (2017) co-inoculated the AMF Glomus aggregatum and the fungus Trichoderma harzanium in basil and concluded that this interaction can reduce the negative effects of nematodes and, at the same time, increase plant growth and EO production. In another study with basil, inoculation with the AMF Glomus intraradices and humic substance (HS) addition (as vermicomposting) also increased the plant growth by $56 \%$ and the EO production by up to $48 \%$ (Verma et al., 2016).

In addition to AMF, HS can affect plant growth and EO production. HS are caused by biological degradation of animal and plant residues and activity of soil microorganisms may affect chemical, physical, and biological properties of soils, increasing plant development, root growth, and total biomass (Befrozfar et al., 2013; Verma et al., 2016; Pandey et al., 2016; Lermen et al., 2017). HS also alter the soil color and improve soil structure, water retention capacity, ion exchange, and buffering power. In addition, they increase the cation exchange capacity and anion exchange capacity, making cations and anions more available to plants (Pinheiro et al., 2010).

Microbes that are harmful to human health are increasingly resistant to the most common antibiotics. The indiscriminate use of antibiotics in the treatment and prevention of diseases has raised the resistance of the disease-causing microbes, a fact observed in different species of animals and in humans. Because of this, the demand for natural antibiotics has increased (Machado et al., 2013).

Many plants and their oils have shown an antimicrobial effect for both Gram-positive and Gram-negative bacteria, as well as fungi, yeasts, viruses, and protozoa (Machado et al., 2012).

Basil (Ocimum basilicum L.) belongs to a group of medicinal plants commonly used in folk medicine. Belonging to the family Lamiaceae, basil species originate from tropical and subtropical regions of Asia, Africa, and Central and South America. The amount of oil extracted from plants can vary in yield, depending on the part of the plant used for extraction, plant age, harvest season, environmental conditions, harvest time, crop seasonality, and soil biotic factors (Urcoviche et al., 2015; Lermen et al., 2015b; Hanif et al., 2017).

The basil EO has been used in food industries as a flavoring for confectionery, nonalcoholic beverages, ice cream, and condiments, as well as in cosmetic industries (Hanif et al., 2017). Some researchers have reported that antimicrobial activities of the basil EO are predominantly associated with its major constituents: estragole and linalool (Elansary et al., 2016; Mith et al., 2016; Avetisyan et al., 2017; Hanif et al., 2017).

Several biotic and abiotic factors can affect plant growth, yield, chemical composition, and antimicrobial activity of EO. Therefore, this study aimed at assessing the effect of HS and AMF [Claroideoglomus etunicatum (=Glomus etunicatum)] on the yield, composition, and antimicrobial activity of the basil EO. It was expected that AMF and HS would increase plant growth and EO yield and modify the oil composition so that it would alter antimicrobial activity.

\section{MATERIAL AND METHODS}

\section{Experiment design and set up}

The soil used in this experiment was collected at the experimental farm of the Paranaense University, UNIPAR, in the Umuarama County (Paraná State) at coordinates $23^{\circ} 46^{\prime} 11.34^{\prime \prime} \mathrm{S}$ and $53^{\circ} 16^{\prime} 41.78^{\prime \prime} \mathrm{W}$, and the soil was classified as dystrophic haplustox (red latosol) (LVd19 - Oxisol) (EMBRAPA - Empresa Brasileira de Pesquisa Agropecuária, 2013).

Genetics and Molecular Research 16 (3): gmr16039710 
The soil was collected at $0-20 \mathrm{~cm}$ in depth to form a sample that was sent for chemical analysis in the "Solo Fértil" Laboratory in Umuarama. Table 1 shows the chemical characteristics of the soil used in this study.

The soil used in the experiment was sieved in a 4-mm mesh and autoclaved at $121^{\circ} \mathrm{C}$ for $1.5 \mathrm{~h}$. Then, the sterile soil was divided into $5-\mathrm{kg}$ pots to receive the treatments. The AMF treatments received the inoculum C. etunicatum at the dosage of 400 spores $/ 100 \mathrm{~g}$ soil per pot (Urcoviche et al., 2015). The control was prepared with $100 \mathrm{~mL}$ of the filtered soil inoculums (100 $\mathrm{g}$ soil inoculum/L deionized water) to isolate the effect of AMF inoculation. Treatments with HS received the product Supra Solo of the Tec Seed Company, which consists of $75 \%$ humic acid and $25 \%$ fulvic acid, at the dose of $2 \mathrm{~L}$ per hectare according to the manufacturer instruction. In the 5-kg pots, the proportion was $5.3 \mathrm{~g}$ HS per $1.325 \mathrm{~L}$ deionized water, applied to those 20 pots corresponding to HS treatments.

Basil seeds were purchased from the FELTRIN Company. Five seeds were sown per pot and after 1 week of germination, thinning was done, leaving two plants per pot. All treatments were irrigated every 2 days as required, with a half concentration of phosphorus of the Hoagland and Arnon (1950) solution. All plants were cultivated in a greenhouse for 4 months.

\section{Spore density and root colonization by AMF}

The spores were extracted from sub-samples of $10 \mathrm{~g}$ soil with wet sieving meshes $(0.710-0.053 \mathrm{~mm})($ Gerdemann and Nicolson, 1963) and were transferred to Petri dishes for counting and identification using a stereoscopic microscope (40X).

Fine roots were collected, bleached, acidified, and colored with trypan blue as Phillips and Hayman (1970). The count of colonized root segments was done on slides overlaid with coverslips (Giovannetti and Mosse, 1980). In total 100 segments were numbered using a stereoscopic microscope (40-100X).

\section{Plant dry matter}

The plants were harvested in the morning $(7-10 \mathrm{am})$ and separated the shoots. A sample of shoots from each treatment was dried in forced air lab oven at $65^{\circ} \mathrm{C}$ for $48 \mathrm{~h}$ and weighed on digital scales for shoot dry matter (SDM).

\section{Essential oil}

The EO was extracted from $200 \mathrm{~g}$ fresh aerial parts in $2 \mathrm{~L}$ deionized water and subjected to hydrodistillation in a modified Clevenger apparatus for $3 \mathrm{~h}$. Extracts were obtained in triplicate for each treatment. The EO was removed from the device with hexane, filtered with anhydrous $\mathrm{Na}_{2} \mathrm{SO}_{4}$, stored in amber flasks, and refrigerated in open flasks until total evaporation of the hexane. Then, each extract was weighed to calculate the EO content (weight/weight \%).

\section{Chemical identification of essential oil via gas chromatography-mass spectrometry analysis}

The EO analysis was carried out in a gas chromatographic system (Agilent 7890 B; Agilent Technologies, Santa Clara, CA, USA), coupled to a mass spectrometer (Agilent 5977

Genetics and Molecular Research 16 (3): gmr16039710 
A) equipped with a column of DB-5 (5\% phenyl methyl siloxane, $30 \mathrm{~m}$ x $0.25 \mathrm{~mm}$ ID, 0.25 $\mu \mathrm{m})$. The following conditions were used: injector temperature of $250^{\circ} \mathrm{C}$, the injection volume of $1 \mu \mathrm{L}$ at a ratio of $1: 2$ (split mode), and an initial column temperature of $40^{\circ} \mathrm{C}$ and heated gradually to $300^{\circ} \mathrm{C}$ at a rate of $8^{\circ} \mathrm{C} / \mathrm{min}$. The carrier gas (helium) flow was set at $1 \mathrm{~mL} / \mathrm{min}$. The temperatures of the transfer line, ion source, and quadrupole were $250^{\circ}, 230^{\circ}$, and $150^{\circ} \mathrm{C}$, respectively. The mass spectra were obtained in a range of $40-500(\mathrm{~m} / \mathrm{z})$ provided through scan mode with a solvent delay time of $3 \mathrm{~min}$, and the compounds were identified based on the comparison of their retention indices obtained using various n-alkanes (C8-C25), according to Adams (2012).

\section{Bacterial minimum inhibitory concentration (MIC)}

Nine bacterium species were used to test MIC of EO (Table 2). A $40 \mu \mathrm{g} / \mathrm{mL}$ EO solution diluted with $2 \%$ polysorbate 80 in Mueller-Hinton broth with $2 \%$ glucose was prepared to treat the isolates. The culture medium $(100 \mu \mathrm{L})$ was distributed into wells of a 96-microdilution plate, and then $200 \mu \mathrm{L}$ EO was added to the second well. Following homogenization, the solution was transferred to the third well, and so on until the tenth well. Thus, the final concentrations obtained after serial dilution were: $40,20,10,5,2.5,1.25,0.625,0.312,0.156$, and $0.078 \mu \mathrm{g} / \mathrm{mL}$. A microbial suspension was prepared in saline with turbidity equivalent to the tube 0.5 of the McFarland scale $\left(1 \times 10^{8}\right.$ UFC - unit-forming colony $\left./ \mathrm{mL}\right)$. Next, the 1:10 bacterial suspension was diluted with Mueller-Hinton broth to obtain $1 \times 10^{4} \mathrm{UFC} / \mathrm{mL}$ as inoculums. Similarly, the 1:50 bacterial suspension was diluted 1:20 in Mueller-Hinton broth to yield $1 \times 10^{5} \mathrm{UFC} / \mathrm{mL}$ as inoculums. The suspensions $(100 \mu \mathrm{L})$ were inoculated in triplicate to each well containing the EO concentrations. The control for sterility was in well number 1 . The toxicity control was $2 \%$ polysorbate 80 in culture medium in well number 11. The growth control was in well number 12 where the microbial suspension was inoculated into the culture medium. Microplates were incubated at $37^{\circ} \mathrm{C}$ for $24 \mathrm{~h}$ under aerobic conditions. The lowest concentration of $\mathrm{EO}$ causing complete inhibition of growth (CLSI, 2009) was reported. A solution of tetracycline (Sigma ${ }^{\mathrm{TM}}$ $250163)$ was used as positive control $(0.078-2.5 \mu \mathrm{g} / \mathrm{mL})$. This antibiotic has a wide range of antimicrobial activity against Gram-positive and Gram-negative bacteria.

\section{Statistical analyses}

The statistical design was completely randomized in a $2 \times 2$-factorial design: 2 levels of HS (with and without) and inoculation (with and without AMF) with 10 replications. Data were submitted to analysis of variance (ANOVA) using a general linear model with mixed-effects and balanced design. Prior to ANOVA, the Levene test was applied to data for homogeneity. Means were compared by the Duncan test $(\mathrm{P} \leq 0.05)$ using the SPSS statistical program, version 22.0, for Windows (SPSS Inc., Chicago, IL, USA).

\section{RESULTS AND DISCUSSION}

Studies with AMF in open fields demonstrate that factors such as pesticides, soil moisture, temperature, $\mathrm{pH}$, soil nutrient content, and light intensity may influence colonization (Smith and Read, 2008). In the greenhouse, the mean temperature ranged from $30.21^{\circ}$ to $35.41^{\circ} \mathrm{C}$ during the 4 months of study.

Genetics and Molecular Research 16 (3): gmr16039710 
The $\mathrm{pH} 5.5$ of the soil used in the experiment (Table 1) is within the range described by Sambatti et al. (2003) for the soils of the Caiuá Sandstone of Umuarama, Paraná. The phosphorus content in the soil was $8.26 \mathrm{mg} / \mathrm{dm}^{3}$, below the values found by Sambatti et al. (2003). It is worth mentioning that low phosphorus content in soil is a favorable condition for root colonization by AMF (Toussaint et al., 2007).

Table 1. Chemical properties of the soil used in the experimental area.

\begin{tabular}{|c|c|c|c|c|c|c|c|c|c|c|c|}
\hline & $\mathrm{pH}\left(\mathrm{CaCl}_{2}\right)$ & $\mathrm{P}\left(\mathrm{mg} / \mathrm{dm}^{3}\right)$ & $\mathrm{C}\left(\mathrm{g} / \mathrm{dm}^{3}\right)$ & $\mathrm{Al}^{3++}$ & $\mathrm{H}^{+}+\mathrm{Al}^{3+}$ & $\mathrm{Ca}^{2+}$ & $\mathrm{Mg}^{2+}$ & $\mathrm{K}^{+}$ & SB & CEC & \\
\hline & & & & & & & $\mathrm{Cmol}_{\mathrm{c}} / \mathrm{dm}^{3}$ & & & & $\%$ \\
\hline Soil ${ }^{\text {a }}$ & 5.51 & 8.26 & 3.19 & 0.00 & 2.8 & 0.88 & 0.38 & 0.18 & 1.44 & 3.72 & 37.86 \\
\hline Reference $^{\mathrm{b}}$ & $3.8-6.6$ & $16-24$ & $0.8-15.9$ & - & $0.6-5.0$ & $0.3-7.2$ & $0.3-3.3$ & $0.1-0.7$ & - & $2.2-12.5$ & - \\
\hline
\end{tabular}

aethods: C: dichromate/colorimetric; $\mathrm{P}$ and $\mathrm{K}$ extracted using Mehlich-I; and Ca, $\mathrm{Mg}$, and $\mathrm{Al}$ extracted using $1 \mathrm{M}$ KCl. CEC: cation exchange capacity; SB: sum of bases; V: base saturation. ${ }^{b}$ Source: Sambatti et al. (2003).

The low carbon content (Table 1) indicates low levels of organic matter in the soil. Thus, the addition of HS would be an important practice to stimulate the growth of basil (Verma et al., 2016).

The soil spore density with AMF inoculation and without HS addition was 2.11 (number of spores/g dry soil); however, with HS addition, it was 3.98 (Table 2). It corresponds to an $89 \%$ increase $(\mathrm{P}<0.001)$ in the AMF spore density. However, it was observed that AMF root colonization did not differ significantly among different doses of HS. In this study, AMF root colonization ranged from 71.1 to $75.8 \%$ among treatments, being this range considered high. In studies performed by Toussaint et al. (2007, 2008), the basil inoculated with Glomus mosseae and Glomus caledonium presented root colonization range of only 15 to $58 \%$.

Table 2. Microbial classification used to minimum inhibitory concentration.

\begin{tabular}{|c|c|c|}
\hline \multirow[t]{4}{*}{ Gram +} & \multicolumn{2}{|c|}{ Bacillus cereus (ATCC-11778) } \\
\hline & \multicolumn{2}{|c|}{ Staphylococcus aureus (ATCC-43300) } \\
\hline & \multicolumn{2}{|c|}{ Staphylococcus epidermidis (ATCC-12228) } \\
\hline & \multicolumn{2}{|c|}{ Listeria innосиа (АТСC-33090) } \\
\hline \multirow[t]{5}{*}{ Gram - } & \multirow[t]{3}{*}{ Proteobacteria } & Escherichia coli (ATCC-25922) \\
\hline & & Salmonella enterica serovar typhi (ATCC-19214) \\
\hline & & Shiguella flexneri (ATCC-12022) \\
\hline & Enterobacteria & Klebsiella pneumoniae (ATCC-13883) \\
\hline & Phytopatogen & Xanthomonas axonopodis pathovar begoniae (ATCC-8718) \\
\hline
\end{tabular}

SDM accumulation was influenced $(\mathrm{P}<0.001)$ by inoculation and addition of $\mathrm{HS}$ to the soil (Table 3). The addition of HS to soil increased plant SDM. However, higher responses in SDM accumulation resulted from AMF inoculation, which doubled the SDM values in comparison with the control (without AMF and HS) (Table 3). This result corroborates with the studies of Khaosaad et al. (2006) and Karagiannidis et al. (2011). The authors observed a significant increase ( 2 to 4.7 times) in the dry mass production of mint and oregano plants when submitted to AMF inoculation. In a recent study, the co-inoculation of the AMF Glomus aggregatum and the fungus Trichoderma harzanium was tested in basil plants, which resulted in increased plant growth and EO production (Tiwari et al., 2017). The authors also observed that this co-inoculation more than doubled the SDM production of basil plants.

Genetics and Molecular Research 16 (3): gmr16039710 
Table 3. Spore density (number of spores/g dry soil) and root colonization (\%) of arbuscular mycorrhizal fungus (AMF), shoot dry matter (SDM, g), and essential oil (EO) yield (\%) of basil non-inoculated and inoculated with Claroideoglomus etunicatum in soil without or with humic substances (HS).

\begin{tabular}{l|l|c|c|c|c}
\hline AMF & HS & Spore density & Colonization & SDM & EO yield* \\
\hline \multirow{2}{*}{ Without } & Without & $0^{\mathrm{c}}$ & $0^{\mathrm{b}}$ & $2.37 \pm 0.27^{\mathrm{c}}$ & $0.05 \pm 0.01^{\mathrm{d}}$ \\
\cline { 2 - 6 } & With & $0^{\mathrm{c}}$ & $0^{\mathrm{b}}$ & $4.12 \pm 0.18^{\mathrm{b}}$ & $0.20 \pm 0.01^{\mathrm{c}}$ \\
\hline \multirow{2}{*}{ With } & Without & $2.11 \pm 0.23^{\mathrm{b}}$ & $71.10 \pm 5.17^{\mathrm{a}}$ & $3.83 \pm 0.43^{\mathrm{b}}$ & $0.29 \pm 0.02^{\mathrm{a}}$ \\
\cline { 2 - 6 } & With & $3.98 \pm 0.73^{\mathrm{a}}$ & $75.80 \pm 4.55^{\mathrm{a}}$ & $5.10 \pm 0.36^{\mathrm{a}}$ & $0.23 \pm 0.02^{\mathrm{b}}$ \\
\hline Significance & $<0.001$ & $<0.001$ & $<0.001$ & $<0.001$ \\
\hline
\end{tabular}

Data are reported as means \pm standard error with ten repetitions. *Five repetitions. Data with different letters in the same column differ significantly by the Duncan test at $5 \%$ probability.

Mycorrhizal associations have benefited growth and development of plants, mainly in low fertile soils, in contrast with non-mycorrhizal plants (Tran and Cavagnaro, 2010). For example, the mycorrhizal inoculation with Glomus intraradices plus an addition of HS to the soil (as vermicomposting) has increased basil growth by $56 \%$ and EO production by up to 48\% (Verma et al., 2016).

As observed in the present study, the positive effects of HS addition, such as the $62 \%$ increase in SDM of non-inoculated plants, could be explained by accelerated root growth, increased plant biomass, and altered root structure. Increased root hairs and thin lateral roots commonly result in a larger surface area and/or longer root system (Befrozfar et al., 2013). The cellular and molecular structure of the action of humic acids is not fully understood yet. However, studies have demonstrated a typical auxin effect from stimulation of the activity and promotion of the synthesis of $\mathrm{H}^{+}$-ATPases in cellular plasma membranes (Canellas et al., 2002). Humic substances, in the form of vermicomposting, have increased growth and production of basil's EO (Pandey et al., 2016; Verma et al., 2016).

The EO yield ranged from 0.05 to $0.29 \%$ (Table 3$)$. The highest EO yield $(0.29 \%)$ was observed in the treatment with AMF and without HS; while the lowest EO yield $(0.05 \%)$ was verified in the treatment without AMF and HS. Other basil studies demonstrated that EO yields ranged from 0.2 to $0.4 \%$ (Barcelos et al., 2013; Hazooumi et al., 2015; Avetisyan et al., 2017), which approximate the values found in this study. According to Verma et al. (2016), HS can cause a partial oxidative phosphorylation in mitochondria, acting as plant growth regulators by increasing the biomass production and, consequently, the content of secondary metabolites, including EOs.

EO yield can be increased by plant association with AMF, which benefit root ramification, improving water absorption and phosphorus uptake. In addition, AMF can also influence the chemical composition of EOs (Copetta et al., 2006, 2007; Hazooumi et al., 2015).

A total of 14 chemical compounds were found in the basil EO (Table 4). Linalool, 1,8 cineole, estragole (methyl chavicol), eugenol, and $\alpha$-trans-Bergamotene were the major compounds identified. The 1,8 cineole content ranged from 7.96 to $10.28 \%$; however, this compound was not found in the control (treatment without AMF and HS). Linalool and estragole were predominant in all treatments, showing contents ranging from 27.53 to $47.17 \%$. AMF inoculation and/or HS addition increased the contents of these two components (Table 4). Linalool and estragole are classified as oxygenated monoterpenes and also appeared as the major compounds of the basil EO cultivated with different levels of zinc (Hanif et al., 2017).

Genetics and Molecular Research 16 (3): gmr16039710 
Table 4. Chemical composition of basil essential oil non-inoculated and inoculated with the arbuscular mycorrhizal fungus (AMF) Claroideoglomus etunicatum in soil without or with humic substances (HS).

\begin{tabular}{|c|c|c|c|c|c|c|c|}
\hline \multirow[t]{2}{*}{ Peak } & \multirow[t]{2}{*}{ Compounds } & \multirow[t]{2}{*}{${ }^{\mathrm{b}} \mathrm{RI}$} & Without AMF and HS & $\begin{array}{c}\text { Without AMF and } \\
\text { with HS }\end{array}$ & $\begin{array}{l}\text { With AMF and } \\
\text { without HS }\end{array}$ & $\begin{array}{l}\text { With AMF } \\
\text { and HS }\end{array}$ & \multirow[t]{2}{*}{$\begin{array}{l}\text { Methods of } \\
\text { identification }\end{array}$} \\
\hline & & & \multicolumn{4}{|c|}{ Area $(\%)$} & \\
\hline 1 & 1,8 Cineol & 990 & $\mathrm{t}$ & 9.60 & 10.28 & 7.96 & $a, b$ \\
\hline 2 & Linalool & 1011 & 28.64 & 39.94 & 42.52 & 37.54 & $\mathrm{a}, \mathrm{b}$ \\
\hline 3 & $\alpha$-Terpineol & 1171 & $\mathrm{t}$ & $t$ & $\mathrm{t}$ & $\mathrm{t}$ & $\mathrm{a}, \mathrm{b}$ \\
\hline 4 & Estragole & 1190 & 27.53 & 44.57 & 47.17 & 35.13 & $\mathrm{a}, \mathrm{b}$ \\
\hline 5 & $\delta$-Elemene & 1300 & $\mathrm{t}$ & $\mathrm{t}$ & $\mathrm{t}$ & $\mathrm{t}$ & $\mathrm{a}, \mathrm{b}$ \\
\hline 6 & Eugenol & 1324 & 33.90 & $\mathrm{t}$ & $\mathrm{t}$ & $\mathrm{t}$ & $a, b$ \\
\hline 7 & $\beta$-Elemene & 1396 & $\mathrm{t}$ & $\mathrm{t}$ & $\mathrm{t}$ & $\mathrm{t}$ & $\mathrm{a}, \mathrm{b}$ \\
\hline 8 & Methyl eugenol & 1414 & $\mathrm{t}$ & $\mathrm{t}$ & $\mathrm{t}$ & $\mathrm{t}$ & $\mathrm{a}, \mathrm{b}$ \\
\hline 9 & (Z)-Isoeugenol & 1416 & $\mathrm{t}$ & $\mathrm{t}$ & $t$ & $t$ & $\mathrm{a}, \mathrm{b}$ \\
\hline 10 & $\alpha$-trans-Bergamotene & 1437 & 9.92 & 5.87 & $\mathrm{t}$ & $\mathrm{t}$ & $\mathrm{a}, \mathrm{b}$ \\
\hline 11 & $\alpha$-Humelene & 1447 & $\mathrm{t}$ & $\mathrm{t}$ & $\mathrm{t}$ & $\mathrm{t}$ & $\mathrm{a}, \mathrm{b}$ \\
\hline 12 & Germacrene D & 1494 & $\mathrm{t}$ & $\mathrm{t}$ & $\mathrm{t}$ & $\mathrm{t}$ & $\mathrm{a}, \mathrm{b}$ \\
\hline 13 & Valencene & 1495 & $\mathrm{t}$ & $\mathrm{t}$ & $\mathrm{t}$ & $\mathrm{t}$ & $\mathrm{a}, \mathrm{b}$ \\
\hline \multirow[t]{2}{*}{14} & Selina-3,7(11) Diene & 1513 & $\mathrm{t}$ & $\mathrm{t}$ & $\mathrm{t}$ & $\mathrm{t}$ & $\mathrm{a}, \mathrm{b}$ \\
\hline & Total identified (\%) & & 99.99 & 99.98 & 99.98 & 99.98 & \\
\hline
\end{tabular}

Compounds listed in order of elution from a DB-5 column. RI: retention index; t: trace. aIdentification based on RI. ${ }^{b}$ Identification based on a comparison of mass spectra.

Eugenol $(33.90 \%)$ was found only in the control and $\alpha$-trans-Bergamotene (5.879.92\%) only in treatments without AMF inoculation. A study with AMF inoculation in basil demonstrated an increase in the EO yield and chemical alterations in the EO composition (Copetta et al., 2007). The authors verified increased contents of some EO compounds, with a predominance of eugenol, followed by linalool, eucalyptol, $\beta$-myrcene, and $\alpha$-terpineol. In the present study, eugenol was not detected in the EO of AMF treatments, but linalool and estragole were found in increased contents. Avetisyan et al. (2017) also found linalool $(68 \%)$ and estragole $(57.3 \%)$ as major compounds of the basil EO. According to the authors, these compounds are responsible for the peculiar aroma of basil and have antioxidant and antimicrobial activities. Linalool and estragole were also the major compounds of the basil EO in studies carried out in India (Elansary et al., 2016; Pandey et al., 2016; Padalia et al., 2017; Tiwari et al., 2017) and Canada (Elansary et al., 2016).

Due to the low EO yield obtained in the control (treatment without AMF and HS), the amount of extracted EO was not sufficient to evaluate the MIC for bacteria showed in Table 2. The antimicrobial activity (MIC) of the basil EO was generally low or inexistent. Among Gram-positive bacteria, Bacillus cereus was inhibited at $1.25 \mathrm{mg} / \mathrm{mL}$ MIC in the treatment without AMF inoculation and with HS addition (Table 5). This was the lowest MIC value found for the basil EO in this study. According to Duarte et al. (2005), this MIC value represents a medium antimicrobial activity. Among Gram-negative bacteria, Salmonella enterica, Shigella flexneri, Klebsiella pneumoniae, and Xanthomonas axonopolis were responsive to the EO antimicrobial effect, with inhibition occurring at $2.5-10.0 \mathrm{mg} / \mathrm{mL}$ MIC. Mith et al. (2016) found a low antimicrobial activity of the basil EO for Salmonella enterica and L. monocytogenes. These authors also found linalool (24.6-29.8\%) and estragole (43-47.7\%) as major compounds of the basil EO.

Klebsiella pneumoniae and Xanthomonas axonopolis were inhibited at $10 \mathrm{mg} / \mathrm{mL}$ MIC in all treatments (Table 5). Shigella flexneri was inhibited at $10 \mathrm{mg} / \mathrm{mL}$ MIC in the treatment with AMF plus HS and at $2.5 \mathrm{mg} / \mathrm{mL}$ MIC in the treatment without AMF and with HS (Table 5). Salmonella enterica was inhibited only in the treatment without AMF and with $\mathrm{HS}$, at $10 \mathrm{mg} / \mathrm{mL} \mathrm{MIC}$ of the EO.

Genetics and Molecular Research 16 (3): gmr16039710 
Table 5. Minimum inhibitory concentration (MIC) of basil essential oil non-inoculated and inoculated with the arbuscular mycorrhizal fungus (AMF) Claroideoglomus etunicatum in soil without or with humic substances (HS).

\begin{tabular}{l|c|c|c}
\hline Microorganisms tested & Without AMF and with HS & With AMF and without HS & With AMF and with HS \\
\cline { 2 - 4 } & \multicolumn{3}{|c}{ MIC $(\mu \mathrm{g} / \mathrm{mL})$} \\
\hline Bacillus cereus (ATCC-11778) & 1.25 & 5 & 2.5 \\
\hline Listeria innocua (ATCC-33090) & $>40$ & $>40$ & $>40$ \\
\hline Staphylococcus aureus (ATCC-43300) & $>40$ & $>40$ & $>40$ \\
\hline Staphylococcus epidermidis (ATCC-12228) & $>40$ & $>40$ & $>40$ \\
\hline Escherichia coli (ATCC-25922) & $>40$ & $>40$ & $>40$ \\
\hline Salmonella enterica serovar typhi (ATCC-19214) & 10 & $>40$ & 10 \\
\hline Shigella flexneri (ATCC-12022) & 2.5 & 10 & 10 \\
\hline Klebsiella pneumoniae (ATCC-13883) & 10 & 10 & 10 \\
\hline Xanthomonas axonopodis pathovar begonia (ATCC-8718) & 10 & & \\
\hline
\end{tabular}

The treatment without AMF and without HS (control) was not tested to MIC due to insufficient EO. A solution of tetracycline was used as positive control $(0.1-2.5 \mathrm{mg} / \mathrm{mL})$ and MIC ranged from 0.1 to 0.22 ( $\pm 0.002 \mathrm{SE})$.

In this study, B. cereus was inhibited at $1.25-5.0 \mathrm{mg} / \mathrm{mL}$ MIC, values below those found by Avetisyan et al. (2017) that reported $6.25 \mathrm{mg} / \mathrm{mL}$ MIC for the bacterium B. subtilis. Generally, Gram-negative bacteria have been more resistant to EOs than Gram-positive bacteria, probably due to the presence of lipophilic compounds of the EOs (Machado et al., 2012). However, in the present study, Gram-negative bacteria were more sensitive to basil EO than Gram-positive bacteria.

Some authors reported antioxidant, insecticide, nematicidal, antifungal, and antibacterial activities of the basil EO (Copetta et al., 2006, 2007; Toussaint et al., 2007; Verma et al., 2016; Avetisyan et al., 2017; Hanif et al., 2017; Tiwari et al., 2017). However, in the present study, the antibacterial effect of the basil EO was low or inexistent. Other characteristics of the basil EO, such as antioxidant, insecticide, nematicidal, and antifungal activities were not tested since the amount of EO extracted of basil plants was not sufficient to perform such analyses.

The composition of the basil EO varied with the different treatments applied. Eugenol was the major compound only in the treatment without AMF and HS. However, AMF inoculation and/or HS addition increased the presence of linalool and estragole, the major compounds found in these conditions. An important point to be considered is the response in growth, yield, and composition of the basil EO after inoculation with other AMF species. Based on alterations verified in the major compounds of the basil EO, according to different treatments, we suggest further studies to assess antioxidant, insecticide, nematicidal, and antimicrobial activities of basil, in addition to investigations on how AMF inoculation and HS addition to crop soils should benefit sustainable production systems, which are a growing concern for farmers and society.

\section{CONCLUSIONS}

HS addition to the soil increased the spore density of the AMF and AMF inoculation and HS addition increased shoot dry mass of the basil.

AMF inoculation and/or HS addition increased EO yield. The composition of the basil EO varied with the different treatments applied. AMF inoculation and/or HS addition increased the presence of linalool and estragole in a range of 27.53-47.17\%. Eugenol (33.39\%) was the major compound only in the control treatment.

The bacteria B. cereus presented the lowest MIC value referent to the basil EO.

Genetics and Molecular Research 16 (3): gmr16039710 


\section{Conflicts of interest}

The authors declare no conflict of interest.

\section{ACKNOWLEDGMENTS}

The authors thank Universidade Paranaense (UNIPAR) by supporting research. F. Morelli thanks the scholarship from CNPq. O. Alberton thanks the National Council for Scientific and Technological Development (CNPq) for a research fellowship.

\section{REFERENCES}

Adams RP (2012). Identification of essential oil components by gas chromatography/mass spectrometry. 4th edn. Allured Publishing Corporation, Carol Stream.

Avetisyan A, Markosian A, Petrosyan M, Sahakyan N, et al. (2017). Chemical composition and some biological activities of the essential oils from basil Ocimum different cultivars. BMC Complement. Altern. Med. 17: 60-67. https://doi. org/10.1186/s12906-017-1587-5

Barcelos RC, Jham GN, Dhingra OD, Mendonça FA, et al. (2013). Identification and quantification of the major fungitoxic components of the Brazilian basil (Ocimum basilicum L.) essential oil. J. Food Res. 2: 124-131. https://doi. org/10.5539/jfr.v2n5p124

Befrozfar MR, Habibi D, Asgharzadeh A, Sadeghi-Shoae M, et al. (2013). Vermicompost, plant growth promoting bacteria and humic acid can affect the growth and essence of basil (Ocimum basilicum L.). Ann. Biol. Res 4: 8-12.

Canellas LP, Olivares FL, Okorokova-Façanha AL and Façanha AR (2002). Humic acids isolated from earthworm compost enhance root elongation, lateral root emergence, and plasma membrane $\mathrm{H}^{+}$-ATPase activity in maize roots. Plant Physiol. 130: 1951-1957. https://doi.org/10.1104/pp.007088

CLSI (2009). Clinical and laboratory standards institute methods for dilution antimicrobial susceptibility tests for bacteria that grow aerobically. 8th edn. Available at [http://pt.scribd.com/doc/89642226/CSLI-2009]. Accessed April 5, 2016.

Copetta A, Lingua G and Berta G (2006). Effects of three AM fungi on growth, distribution of glandular hairs, and essential oil production in Ocimum basilicum L. var. Genovese. Mycorrhiza 16: 485-494. https://doi.org/10.1007/ $\underline{\mathrm{s} 00572-006-0065-6}$

Copetta A, Lingua G, Bardi L, Masoero G, et al. (2007). Influence of Arbuscular mycorrhizal fungi on growth and essential oil composition in Ocimum basilicum var. Genovese. Caryologia 60: 106-110. https://doi.org/10.1080/00087114.2 $\underline{007.10589555}$

Duarte MCT, Figueira GM, Sartoratto A, Rehder VLG, et al. (2005). Anti-Candida activity of Brazilian medicinal plants. J. Ethnopharmacol. 97: 305-311. https://doi.org/10.1016/j.jep.2004.11.016

Elansary HO, Yessoufou K, Shokaralla S, Mahmoud EA, et al. (2016). Enhancing mint and basil oil composition and antibacterial activity using seaweed extracts. Ind. Crops Prod. 92:50-56. https://doi.org/10.1016/j.indcrop.2016.07.048

EMBRAPA - Empresa Brasileira de Pesquisa Agropecuária (2013). Sistema brasileiro de classificação de solos. $3^{\mathrm{a}}$ ed. Brasília.

Gerdemann JW and Nicolson TH (1963). Spores of mycorrhizal endogone species extracted from soil by wet sieving and decanting. Trans. Br. Mycol. Soc. 46: 235-244. https://doi.org/10.1016/S0007-1536(63)80079-0

Giovannetti M and Mosse B (1980). An evaluation of techniques for measuring VA mycorrhizal infection in roots. New Phytol. 84: 489-500. https://doi.org/10.1111/j.1469-8137.1980.tb04556.x

Hanif MA, Nawaz H, Ayub MA, Tabassum N, et al. (2017). Evaluation of the effects of zinc on the chemical composition and biological activity of basil essential oil by using Raman spectroscopy. Ind. Crops Prod. 96: 91-101. https://doi. org/10.1016/j.indcrop.2016.10.058

Hazzoumi Z, Moustakime Y, Elharchili EH, Joutei KA, et al. (2015). Effect of arbuscular mycorrhizal fungi (AMF) and water stress on growth, phenolic compounds, glandular hairs, and yield of essential oil in basil (Ocimum gratissimum L). Chem. Biol. Technol. Agric 2: 10-21. https://doi.org/10.1186/s40538-015-0035-3

Hoagland DR and Arnon DI (1950). The water-culture method for growing plants without soil. 2nd edn. Calif. Agr. Exp. 347. Karagiannidis N, Thomidis T, Lazari D, Panou-Filotheou E, et al. (2011). Effect of three Greek arbuscular mycorrhizal fungi in improving the growth, nutrient concentration, and production of essential oils of oregano and mint plants. Sci. Hortic. (Amsterdam) 129: 329-334. https://doi.org/10.1016/j.scienta.2011.03.043

Genetics and Molecular Research 16 (3): gmr16039710 
Khaosaad T, Vierheilig H, Nell M, Zitterl-Eglseer K, et al. (2006). Arbuscular mycorrhiza alter the concentration of essential oils in oregano (Origanum sp., Lamiaceae). Mycorrhiza 16: 443-446. https://doi.org/10.1007/s00572-006-0062-9

Lermen C, Cruz RMS, Souza JS, Marchi BA et al. (2017). Growth of Lippia alba (Mill.) N. E. Brown inoculated with arbuscular mycorrhizal fungi with different levels of humic substances and phosphorus in the soil. J. Appl. Res. Med. Aromat. Plants. http://dx.doi.org/10.1016/j.jarmap.2017.05.002.

Lermen C, Mohr FBM and Alberton O (2015a). Growth of Cymbopogon citratus inoculated with mycorrhizal fungi under different levels of lead. Sci. Hortic. (Amsterdam) 186: 239-246. https://doi.org/10.1016/j.scienta.2015.02.029

Lermen C, Morelli F, Gazim ZC, da Silva AP, et al. (2015b). Essential oil content and chemical composition of Cymbopogon citratus inoculated with arbuscular mycorrhizal fungi under different levels of lead. Ind. Crops Prod. 76: 734-738. https://doi.org/10.1016/j.indcrop.2015.07.009

Machado BAS, Ribeiro DS and Druzian JI (2013). Estudo prospectivo relativo à atividade antimicrobiana de algumas plantas aromáticas. Cad. Prospec 6: 97-105. https://doi.org/10.9771/S.CPROSP.2013.006.012

Machado TF, Pereira RCA, Nogueira NAP, Sousa CT, et al. (2012). Atividade antimicrobiana do óleo essencial de manjericão contra patógenos e deterioradores de alimentos. Embrapa Agroindústria Tropical, Fortaleza.

Mith H, Yayi-Ladékan E, Kpoviessi SDS, Bokossa IY, et al. (2016). Chemical composition and antimicrobial activity of essential oils of Ocimum basilicum, Ocimum canum and Ocimum gratissimum in function of harvesting time. $J$. Essent. Oil Bear. Plants 19: 1413-1425. https://doi.org/10.1080/0972060X.2014.890076

Mohr FBM, Lermen C, Gazim ZC, Gonçalves JE, et al. (2017). Antifungal activity, yield, and composition of Ocimum gratissimum essential oil. Genet. Mol. Res. 16: gmr16019542. https://doi.org/10.4238/gmr16019542

Padalia RC, Verma RS, Upadhyay RK, Chauhan A, et al. (2017). Productivity and essential oil quality assessment of promising accessions of Ocimum basilicum L. from north India. Ind. Crops Prod. 97: 79-86. https://doi.org/10.1016/j.indcrop.2016.12.008

Pandey V, Patel A and Patra DD (2016). Biochar ameliorates crop productivity, soil fertility, essential oil yield and aroma profiling in basil (Ocimum basilicum L.). Ecol. Eng. 90: 361-366. https://doi.org/10.1016/j.ecoleng.2016.01.020

Phillips JM and Hayman DS (1970). Improved procedures for clearing roots and staining parasitic and vesicular-arbuscular mycorrhizal fungi for rapid assessment of infection. Trans. Br. Mycol. Soc. 55: 157-160. https://doi.org/10.1016/ $\underline{\text { S0007-1536(70)80110-3 }}$

Pinheiro GL, Silva CA and Furtini Neto AE (2010). Crescimento e nutrição de clone de eucalipto em resposta à aplicação de concentrações de c-ácido húmico. Rev. Bras. Ciênc. Solo 34: 1217-1229. https://doi.org/10.1590/S0100$\underline{06832010000400021}$

Sambatti JA, Souza IG, Junior., Costa ACS and Tormena CA (2003). Estimativa da acidez potencial pelo método do $\mathrm{pH}$ SMP em solos da formação Caiuá - Noroeste do estado do Paraná. Rev. Bras. Ciênc. Solo 27: 257-264. https://doi. org/10.1590/S0100-06832003000200006

Smith SE and Read DJ (2008). Mycorrhizal symbiosis. 3rd edn. Academic Press, New York.

Tiwari S, Pandey S, Chauhan PS and Pandey R (2017). Biocontrol agents in co-inoculation manages root knot nematode [Meloidogyne incognita (Kofoid \& White) Chitwood] and enhances essential oil content in Ocimum basilicum L. Ind. Crops Prod. 97: 292-301. https://doi.org/10.1016/j.indcrop.2016.12.030

Toussaint JP, Smith FA and Smith SE (2007). Arbuscular mycorrhizal fungi can induce the production of phytochemicals in sweet basil irrespective of phosphorus nutrition. Mycorrhiza 17: 291-297. https://doi.org/10.1007/s00572-006-0104-3

Toussaint JP, Kraml M, Nell M, Smith SE, et al. (2008). Effect of Glomus mosseae on concentrations of rosmarinic and caffeic acids and essential oil compounds in basil inoculated with Fusarium oxysporum f. sp. basilici. Plant Pathol. 57: 1109-1116. https://doi.org/10.1111/j.1365-3059.2008.01895.x

Tran J and Cavagnaro TR (2010). Growth and mycorrhizal colonization of two grasses in soils with different inundation histories. J. Arid Environ. 74: 715-717. https://doi.org/10.1016/j.jaridenv.2009.10.017

Urcoviche RC, Castelli M, Gimenes RMT and Alberton O (2014). Spore density and diversity of arbuscular mycorrhizal fungi in medicinal and seasoning plant. Afr. J. Agric. Res. 9: 1244-1251.

Urcoviche RC, Gazim ZC, Dragunski DC, Barcellos FG, et al. (2015). Plant growth and essential oil content of Mentha crispa inoculated with arbuscular mycorrhizal fungi under different levels of phosphorus. Ind. Crops Prod. 67: 103107. https://doi.org/10.1016/j.indcrop.2015.01.016

Verma SK, Pankaj U, Khan K, Singh R, et al. (2016). Bioinoculants and vermicompost improve Ocimum basilicum yield and soil health in a sustainable production system. Clean - Soil Air Water 44: 686-693.

Zubek S, Stefanowicz AM, Blaszkowski J, Niklinska M, et al. (2012). Arbuscular mycorrhizal fungi and soil microbial communities under contrasting fertilization of three medicinal plants. Appl. Soil Ecol. 59: 106-115. https://doi. org/10.1016/j.apsoil.2012.04.008

Genetics and Molecular Research 16 (3): gmr16039710 